\title{
Parasites of cetaceans stranded on the Pacific coast of Costa Rica
}

\author{
J.B. Oliveira ${ }^{\mathrm{a}, \mathrm{b}, *}$, J.A. Morales ${ }^{\mathrm{c}}$, R.C. González-Barrientos ${ }^{\mathrm{c}, \mathrm{d}}$, J. Hernández-Gamboa ${ }^{\mathrm{a}}$, \\ G. Hernández-Mora d,e,f \\ a Cátedra de Parasitologia, Departamento de Biologia, Universidade Federal Rural de Pernambuco (UFRPE), Rua Dom Manoel de Medeiros SN, \\ Recife, CEP 52171-900, Pernambuco, Brazil \\ b Cátedra de Parasitología y Enfermedades Parasitarias, Escuela de Medicina Veterinaria, Universidad Nacional (UNA), Apdo 86-3000, Barreal de Heredia, \\ Heredia, Costa Rica \\ c Departamento de Patología, Escuela de Medicina Veterinaria, Universidad Nacional (UNA), Apdo 86-3000, Barreal de Heredia, Heredia, Costa Rica \\ d Área de Patología, LANASEVE-SENASA-MAG, Heredia, Costa Rica \\ e Programa de Investigación en Enfermedades Tropicales (PIET), Escuela de Medicina Veterinaria, Universidad Nacional (UNA), Apdo 86-3000, \\ Barreal de Heredia, Heredia, Costa Rica \\ ${ }^{\mathrm{f}}$ Fundación Keto, Apdo 1735-1002, San José, Costa Rica
}

\section{A R T I C L E I N F O}

\section{Article history:}

Received 7 May 2010

Received in revised form 31 March 2011

Accepted 12 May 2011

\section{Keywords:}

Dolphin

Whale

Helminth

Pathology

Stranding

Pacific Sea

\begin{abstract}
A B S T R A C T
Information regarding parasitic fauna of cetaceans from Costa Rica is provided for the first time. A total of 25 stranded dolphins and whales were examined between 2001 and 2009 , including striped dolphin (Stenella coeruleoalba) $(n=19)$, pantropical spotted dolphin (S. attenuata) $(n=2)$, spinner dolphin (S. longirostris) $(n=1)$, bottlenose dolphin (Tursiops truncatus) $(n=1)$, dwarf sperm whale (Kogia sima) $(n=1)$ and Cuvier's beaked whale (Ziphius cavirostris) $(n=1)$. Pathological findings associated with the parasites are also presented. In the most representative dolphin species, $S$. coeruleoalba, the prevalence of parasites was $89.5 \%$; moreover, all examined specimens of $S$. attenuata, S. longirostris, T. truncatus and $Z$. cavirostris presented parasites. No parasites were recovered from $K$. sima. Fourteen helminth taxa were identified, including six species of cestodes (Strobilocephalus triangularis, Tetrabothrius forsteri, Trigonocotyle sp., Phyllobothrium delphini, Monorygma grimaldi, Tetraphyllidea gen. sp. plerocercoid), four digeneans (Nasitrema globicephalae, Brachycladium palliatum, B. pacificum and Oschmarinella albamarina) and four nematodes (Anisakis spp., Halocercus lagenorhynchi, Halocercus sp. and Crassicauda anthonyi). A commensal crustacean, Xenobalanus globicipitis, was also identified. All identified parasites representing new geographic records for the Pacific coast of Central America and new host records are presented. Parasitological information is valuable for conservation of cetaceans in Pacific coast of Costa Rica.
\end{abstract}

(C) 2011 Elsevier B.V. All rights reserved.

\footnotetext{
* Corresponding author at: Cátedra de Parasitologia, Departamento de Biologia, Universidade Federal Rural de Pernambuco (UFRPE), Rua Dom Manoel de Medeiros SN, Recife, CEP 52171-900, Pernambuco, Brazil. Tel.: +55 33206331 .

E-mail addresses: bianque01@yahoo.com.br, jaqueline@db.ufrpe.br (J.B. Oliveira).
}

\section{Introduction}

The design and implementation of conservation plans for marine mammals is a matter of public concern. However, very little is known about the role of parasites in the dynamics of marine mammal populations (Raga et al., 1997). These animals commonly strand or are washed ashore along ocean beaches and the post mortem examination of them may provide information on causes of their death (Dailey and Walker, 1978; Raga et al., 1997; Gibson 
et al., 1998; Jaber et al., 2006). The parasitic diseases as a factor in cetacean stranding behavior is still an area of current speculation, although for some authors the parasites are considered as a cause of debilitation or death (Dailey and Stroud, 1978; Stroud and Roffe, 1979; Gibson et al., 1998; Dailey, 2001; Jaber et al., 2006). Damage and mortality of individuals and populations caused by parasitic infections are dependent upon several factors, including the parasite species, its abundance, the health status of the host and competition with other pathogens (Raga et al., 2002).

Most Costa Rican marine mammals are cetaceans (5 families, 18 genera and 30 species), representing about $36 \%$ of the 83 species known worldwide, and $39 \%$ of all Latin American marine mammal species (Wehrtmann and Cortés, 2009). About 27 marine mammal species have been observed or are expected to occur in the Pacific (96.5\% are confirmed) and 29 (only 28\% are confirmed) in the Caribbean waters of Costa Rica (Wehrtmann and Cortés, 2009). Cetaceans are hosts of a great variety of parasites, which include nematodes, cestodes, trematodes, acanthocephalans and crustaceans (Aznar et al., 1994; Cerioni and Mariniello, 1996; Mignucci-Giannoni et al., 1998; Dailey, 2001; Fertl, 2002; Fernández et al., 2004; Colón-Llavina et al., 2009). Nevertheless, the parasite fauna of cetaceans from Costa Rica are unknown thereby the information gathered is valuable for conservation of these mammals.

In this work we provide the first records for parasite fauna of dolphins, dwarf sperm whale and Cuvier's beaked whale found stranded or dead along the Costa Rican Pacific coast. Additionally, pathological findings associated with them are also presented.

\section{Materials and methods}

Internal parasites were collected from 25 stranded and dead dolphins and whales on the Pacific coast from Costa Rica, during the period 2001-2009. In this period the following cetaceans were studied: 19 striped dolphin (Stenella coeruleoalba), 2 pantropical spotted dolphin (S. attenuata, previously known as S. graffmani), 1 spinner dolphin (S. longirostris), 1 bottlenose dolphin (Tursiops truncatus), 1 dwarf sperm whale (Kogia sima), and 1 Cuvier's beaked whale (Ziphius cavirostris). Biological data and geographic localities of these animals are presented in Table 1.

Either dead or moribund cetaceans were collected from the beach by the participants and volunteers of the Fundación Keto and transported to the Departamento de Patología, Escuela de Medicina Veterinaria, Universidad Nacional de Costa Rica where the necropsies were carried on. During necropsy, major organ systems were analyzed, including skin, blubber, muscles, abdominal cavity, alimentary system (esophagus, stomach, small and large intestine, liver and pancreatic blood vessels, hepatic and pancreatic ducts), urinary system (kidneys, ureters and urinary bladder), reproductive system, thoracic cavity, respiratory system (air sinuses, trachea, bronchi and lungs), and central nervous system. Animals were necropsied fresh or refrigerated but never frozen. Samples of affected tissues were fixed in $10 \%$ buffered neutral formalin and processed for conventional histopathology examination.
Table 1

Biological data and geographic localities of stranded cetaceans on the Pacific coast of Costa Rica, 2001-2009.

\begin{tabular}{|c|c|c|}
\hline Species/case number & Sex/age & Beach/province \\
\hline \multicolumn{3}{|l|}{ Stenella coeruleoalba: } \\
\hline ND14701 & $\mathrm{F} / \mathrm{J}$ & Hermosa, Guanacaste \\
\hline N9303 & $\mathrm{M} / \mathrm{J}$ & Undetermined \\
\hline N16503 & $\mathrm{F} / \mathrm{U}$ & Playa Grande, Guanacaste \\
\hline ND12504 & $\mathrm{F} / \mathrm{U}$ & Tambor, Puntarenas \\
\hline NP14004 & $\mathrm{F} / \mathrm{U}$ & Osa, Puntarenas \\
\hline ND2105 & $\mathrm{M} / \mathrm{A}$ & Matapalo, Puntarenas \\
\hline ND2505 & $\mathrm{M} / \mathrm{J}$ & Matapalo, Puntarenas \\
\hline ND3005 & $\mathrm{F} / \mathrm{A}$ & Tambor, Puntarenas \\
\hline ND3805 & $\mathrm{F} / \mathrm{J}$ & Tambor, Puntarenas \\
\hline ND1406 & $\mathrm{F} / \mathrm{A}$ & Tambor, Puntarenas \\
\hline ND2506 & $\mathrm{F} / \mathrm{J}$ & Bahia Ballena, Puntarenas \\
\hline ND3106 & $\mathrm{M} / \mathrm{J}$ & Esterillos Oeste, Puntarenas \\
\hline ND7506 & $\mathrm{F} / \mathrm{A}$ & Guacalillo, Puntarenas \\
\hline ND2307 & $\mathrm{M} / \mathrm{J}$ & Matapalo, Puntarenas \\
\hline ND2407 & $\mathrm{F} / \mathrm{A}$ & San Isidro, Puntarenas \\
\hline ND8107 & $\mathrm{F} / \mathrm{A}$ & Quepos, Puntarenas \\
\hline ND5808 & $\mathrm{M} / \mathrm{J}$ & Puntarenas, Puntarenas \\
\hline ND5509 & $\mathrm{M} / \mathrm{J}$ & Barú, Puntarenas \\
\hline ND7309 & $\mathrm{F} / \mathrm{A}$ & Malpaís, Punterenas \\
\hline \multicolumn{3}{|l|}{ S. attenuata: } \\
\hline ND204 & $\mathrm{M} / \mathrm{J}$ & Matapalo, Puntarenas \\
\hline ND0109 & $\mathrm{M} / \mathrm{S}$ & Bajamar, Puntarenas \\
\hline \multicolumn{3}{|l|}{ S. longirostris: } \\
\hline ND7207 & $\mathrm{F} / \mathrm{J}$ & Tamarindo, Guanacaste \\
\hline \multicolumn{3}{|l|}{ Tursiops truncatus: } \\
\hline ND3909 & $\mathrm{F} / \mathrm{A}$ & Bahia Salinas, Guanacaste \\
\hline \multicolumn{3}{|l|}{ Kogia sima: } \\
\hline ND6106 & $\mathrm{F} / \mathrm{C}$ & Matapalo, Puntarenas \\
\hline \multicolumn{3}{|l|}{ Ziphius cavirostris: } \\
\hline ND4009 & $\mathrm{F} / \mathrm{A}$ & Matapalo, Puntarenas \\
\hline
\end{tabular}

A - adult; C - calf; F - female; J - juvenile; $\mathrm{M}$ - male; $\mathrm{S}$ - senile; $\mathrm{U}$ undetermined.

Where the collection of all parasites specimens was not feasible, representative samples were taken. The parasites recovered during post mortem examination were transported to the laboratory, washed in physiological saline, and fixed and preserved in $70 \%$ ethanol or (93 parts 70\% ethanol: 5 parts 10\% formaldehyde: 2 parts acetic acid) AFA. Because the examination of all of the specimens under light microscope was not feasible, so the samples were scanned and sorted under stereomicroscope and representatives of the different forms were prepared for examination under light microscope. The staining and mounting of the helminths were carried out as described by Gibson et al.(1998). Platyhelminth specimens were stained with Mayer's paracarmine, dehydrated in an alcohol series, cleared in beechwood creosote and mounted in Canada balsam, whereas nematodes were examined as wet-mounts in clearing agents, such as glycerin (for small worms), lactophenol or beechwood creosote (for large worms). These compounds were removed from the specimens by the use of acid-alcohol prior to their being returned to the storage ethanol or AFA. On the other hand, the plerocercoids were processed as described by Agusti et al. (2005a). Most plerocercoids were collected alive and were stained with eosin, dehydrated in $70 \%(\mathrm{v} / \mathrm{v})$ ethanol, and cleared with lactophenol.

Barnacles were observed under a stereomicroscope. The identification was based on Rajaguru and Shantha (1992). 
Table 2

Parasites and commensals of cetaceans stranded on the Pacific coast of Costa Rica, 2001-2009.

\begin{tabular}{|c|c|c|}
\hline Species/case number & Parasites & Infected organ \\
\hline \multicolumn{3}{|l|}{ Stenella coeruleoalba: } \\
\hline \multirow{4}{*}{ ND14701 } & Tetrabothrius forsteri & Intestine \\
\hline & Tetraphyllidean plerocercoids & Anal crypts \\
\hline & Anisakis spp. & Stomach \\
\hline & Halocercus lagenorhynchi & Lungs \\
\hline \multirow[t]{4}{*}{ N9303 } & T. forsteri & Intestine \\
\hline & Tetraphyllidean plerocercoids & Anal crypts \\
\hline & Anisakis spp. & Stomach and intestine \\
\hline & H. lagenorhynchi & Lungs \\
\hline \multirow{3}{*}{ N16503 } & T. forsteri & Intestine \\
\hline & Tetraphyllidean plerocercoids & Anal crypts \\
\hline & Anisakis spp. & Stomach and intestine \\
\hline \multirow{4}{*}{ ND12504 } & T. forsteri & Intestine \\
\hline & Tetraphyllidean plerocercoids & Anal crypts \\
\hline & Anisakis spp. & Esophagus and stomach \\
\hline & H. lagenorhynchi & Lungs \\
\hline \multirow[t]{3}{*}{ ND2505 } & T. forsteri & Intestine \\
\hline & Tetraphyllidean plerocercoids & Anal crypts \\
\hline & Anisakis spp. & Stomach \\
\hline \multirow[t]{2}{*}{ ND3005 } & Anisakis spp. & Stomach \\
\hline & H. lagenorhynchi & Lungs \\
\hline \multirow[t]{2}{*}{ ND3805 } & T. forsteri & Intestine \\
\hline & Anisakis spp. & Esophagus and stomach \\
\hline \multirow{3}{*}{ ND1406 } & Tetraphyllidean plerocercoids & Anal crypts \\
\hline & Anisakis spp. & Esophagus and stomach \\
\hline & H. lagenorhynchi & Lungs \\
\hline \multirow[t]{3}{*}{ ND2506 } & T. forsteri & Intestine \\
\hline & Anisakis spp. & Stomach \\
\hline & H. lagenorhynchi & Lungs \\
\hline \multirow[t]{3}{*}{ ND3106 } & T. forsteri & Intestine \\
\hline & Anisakis spp. & Stomach and intestine \\
\hline & H. lagenorhynchi & Lungs \\
\hline \multirow[t]{6}{*}{ ND7506 } & T. forsteri & Intestine \\
\hline & Strobilocephalus triangularis & Colon \\
\hline & Phyllobothrium delphini & Subcutaneous blubber \\
\hline & Monorygma grimaldi & Parallel to the rectum \\
\hline & Anisakis spp. & Stomach and intestine \\
\hline & H. lagenorhynchi & Lungs \\
\hline \multirow[t]{3}{*}{ ND2307 } & S. triangularis & Colon \\
\hline & P. delphini & Subcutaneous blubber \\
\hline & Anisakis spp. & Stomach \\
\hline \multirow[t]{7}{*}{ ND2407 } & T. forsteri & Intestine \\
\hline & Tetraphyllidean plerocercoids & Anal crypts, hepatic and pancreatic ducts \\
\hline & P. delphini & Subcutaneous blubber \\
\hline & M. grimaldi & Caudal area of the kidneys \\
\hline & Brachycladium palliatum & Hepatic and pancreatic ducts \\
\hline & Anisakis spp. & Esophagus, stomach, intestine \\
\hline & H. lagenorhynchi & Lungs \\
\hline ND8107 & T. forsteri & Intestine \\
\hline & Anisakis spp. & Stomach \\
\hline & H. lagenorhynchi & Lungs \\
\hline ND5808 & T. forsteri & Intestine \\
\hline & Tetraphyllidean plerocercoids & Anal crypts \\
\hline & Anisakis spp. & Esophagus, stomach and intestine \\
\hline & H. lagenorhynchi & Lungs \\
\hline & Xenobalanus globicipitis & Skin (caudal fluke) \\
\hline ND5509 & T. forsteri & Intestine \\
\hline & P. delphini & Subcutaneous blubber \\
\hline & M. grimaldi & Testis \\
\hline & Nasitrema globicephalae & Air sinuses \\
\hline & Anisakis spp. & Stomach \\
\hline & H. lagenorhynchi & Lungs \\
\hline ND7309 & P. delphini & Subcutaneous blubber \\
\hline Stenella attenuata: & & \\
\hline ND204 & Tetraphyllidean plerocercoids & Anal crypts \\
\hline & Anisakis spp. & Stomach \\
\hline & Halocercus sp. & Lungs \\
\hline
\end{tabular}


Table 2 (Continued)

\begin{tabular}{|c|c|c|}
\hline Species/case number & Parasites & Infected organ \\
\hline \multirow[t]{6}{*}{ ND0109 } & T. forsteri & Intestine \\
\hline & M. grimaldi & Testis \\
\hline & N. globicephalae & Air sinuses \\
\hline & Trematodes eggs & Lungs \\
\hline & Anisakis spp. & Stomach \\
\hline & $X$. globicipitis & Skin (caudal fluke) \\
\hline \multicolumn{3}{|l|}{ Stenella longirostris: } \\
\hline \multirow[t]{4}{*}{ ND7207 } & Trigonocotyle sp. & Intestine \\
\hline & B. pacificum & Hepatic and pancreatic ducts \\
\hline & Anisakis spp. & Stomach \\
\hline & Halocercus sp. & Lungs \\
\hline \multicolumn{3}{|l|}{ Tursiops truncatus: } \\
\hline ND3909 & M. grimaldi & Ligament of the uterus \\
\hline \multicolumn{3}{|l|}{ Ziphius cavirostris: } \\
\hline \multirow[t]{3}{*}{ ND4009 } & Oschmarinella albamarina & Hepatic and pancreatic ducts \\
\hline & Anisakis spp. & Stomach \\
\hline & Crassicauda anthonyi & Kidney \\
\hline
\end{tabular}

The numerical data collected are restricted to prevalence (Bush et al., 1997). Accurate estimates of intensity of infection were generally not possible.

\section{Results}

Overall, five of six cetacean species had parasites. In the most representative dolphin, $S$. coeruleoalba, prevalence of parasites was $89.5 \%$; moreover, all examined specimens of S. attenuata, S. longirostris, $T$. truncatus and Z. cavirostris presented parasites. No parasites were recovered from the dwarf sperm whale calf $K$. sima.

Fourteen helminth taxa were found and morphologically identified, including six species of cestodes, four digeneans and four nematodes. The nematodes and cestodes were the most prevalent parasite groups (90.9\%), followed by the digeneans $(22.7 \%)$. The most prevalent species were Anisakis spp. (90.9\%), followed by Tetrabothrius forsteri (63.6\%), Halocercus lagenorhynchi (54.5\%) and tetraphyllidean plerocercoids (40.9\%).

Additionally, a commensal crustacean species was also found and identified.

Data of the hosts, parasites and infected organs, and prevalence of identified parasites are presented in Tables 2 and 3.

\subsection{Eucestoda}

Were collected many metacestodes (plerocercoids and merocercoids), scolices, strobilar fragments, and complete specimens of cestodes. Three cestodes species (Eucestoda, Tetrabothriidae) from the intestine of dolphins were identified: T. forsteri (63.6\%) in S. coeruleoalba and S. attenuata; Strobilocephalus triangularis (9.1\%) in S. coeruleoalba, and Trigonocotyle sp. (4.5\%) in S. longirostris. Specimens of $T$. forsteri (Fig. 1) and Trigonocotyle sp. were recovered mainly from duodenum, whereas complete specimens of $S$. triangularis were recovered from the terminal colon. The enormous scolices of $S$. triangularis were deeply embedded in the sub-mucosa, no associated with lesions.

Two species of tetraphyllidean merocercoids were also collected: merocercoids of Phyllobothrium delphini (Eucestoda, Phylobothriidae) were encysted in the ven- tral abdominal subcutaneous blubber (Fig. 1) from S. coeruleoalba, whereas merocercoids of Monorygma grimaldi (Eucestoda, Phylobothriidae) were retroperitoneally encysted parallel to the rectum, in the caudal pole of the kidneys, in the broad ligament of the uterus and close to the testis (Fig. 1). Species infected with M. grimaldi were S. coeruleoalba, S. attenuata and T. truncatus. P. delphini and $M$. grimaldi presented the same prevalence (22.7\%).

Tetraphyllidean plerocercoids (40.9\%) were found inside the anal crypts (100\%) and free in the hepatic and pancreatic ducts (11.1\%) from $S$. coeruleoalba and $S$. attenuata. Two morphotypes were recognized: "small" plerocercoids (SP) and "large" plerocercoids (LP), according to the descriptions of Agusti et al. (2005a) and Aznar et al. (2007).

\subsection{Digenea}

Four digeneans of Brachycladiidae family (previously known as Campulidae and Nasitrematidae) were identified: Nasitrema globicephalae (9.1\%), Brachycladium palliatum (4.5\%), B. pacificum (4.5\%) and Oschmarinella alba-

Table 3

Prevalence of parasites and commensals of cetaceans stranded on the Pacific coast of Costa Rica, 2001-2009.

\begin{tabular}{lc}
\hline Parasites & No. infected (prevalence \%) \\
\hline Anisakis spp. & $20(90.9)$ \\
Tetrabothrius forsteri & $14(63.6)$ \\
Halocercus lagenorhynchi & $12(54.5)$ \\
Tetraphyllidean plerocercoids & $9(40.9)$ \\
Phyllobothrium delphini & $5(22.7)$ \\
Monorygma grimaldi & $5(22.7)$ \\
Halocercus sp. & $2(9.1)$ \\
Strobilocephalus triangularis & $2(9.1)$ \\
Nasitrema globicephalae & $2(9.1)$ \\
X. globicipitis & $2(9.1)$ \\
Trigonocotyle sp. & $1(4.5)$ \\
Brachycladium palliata & $1(4.5)$ \\
B. pacificum & $1(4.5)$ \\
Oschmarinella albamarina & $1(4.5)$ \\
Crassicauda anthonyi & $1(4.5)$ \\
Total & $22(88.0)$ \\
\hline
\end{tabular}


marina (4.5\%). The identification of digeneans was made according to Gibson and Bray (1997) and Gibson (2005).

Specimens of $N$. globicephalae were found in air sinuses (Fig. 1) of S. coeruleoalba and S. attenuate. The parasites (more than 40 trematodes per host) were associated with multiple erosions and mild sinusitis in infected dolphins. Moreover, the specimen of $S$. attenuata presented perineuristis in eighth cranial nerve (vestibulocochlear nerve). In a spotted dolphin S. attenuata (ND0109), which have adults of $N$. globicephalae in air sinuses, also were found trematode eggs in the mucous collected from the lungs. A slight granulomatous pneumonia was associated to the presence of eggs.
Liver flukes B. palliatum (Fig. 1), B. pacificum and $O$. albamarina (Fig. 1) were recovered from the hepatic and pancreatic ducts of $S$. coeruleoalba, S. longirostris and $Z$. cavirostris respectively. All infected cetaceans presented a slight nonsuppurative cholangitis associated with the presence of parasites.

\subsection{Nematoda}

Were identified nematodes of three genera: Anisakis (Nematoda, Anisakidae), Halocercus (Nematoda, Pseudaliidae) and Crassicauda (Nematoda, Tetrameridae).
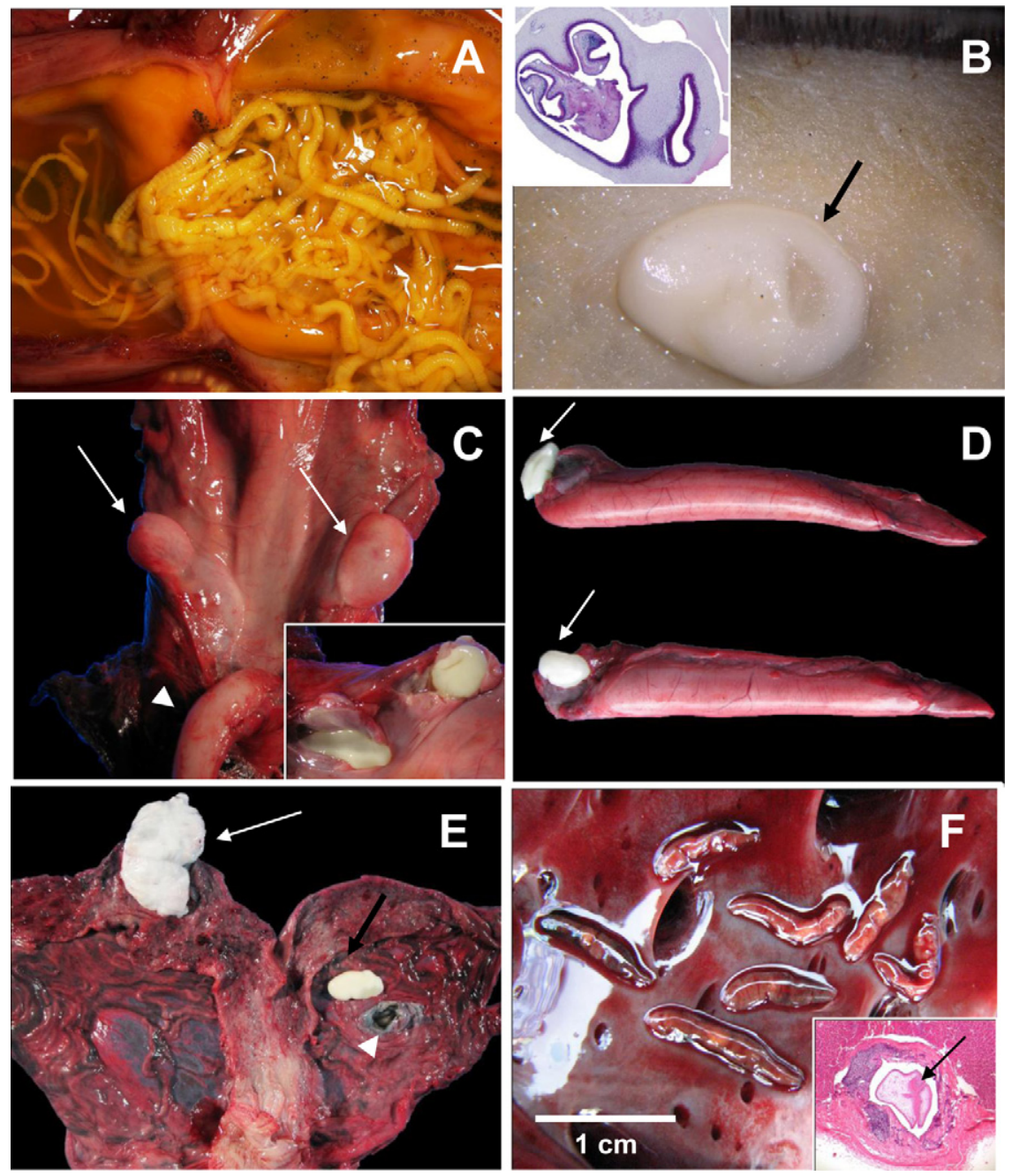

Fig. 1. Parasites of cetaceans stranded on the Pacific coast of Costa Rica, 2001-2009: (A) Tetrabothrius forsteri in the duodenum of striped dolphin Stenella coeruleoalba. (B) Phyllobothrium delphini cyst in the blubber of the abdominal area of S. coeruleoalba (black arrow); insert shows a histological section of this merocercoid (H\&E X4). (C) Two cysts of Monorygma grimaldi (white arrows) close to the rectum (arrow head) from S. coeruleoalba; insert shows opened cyst with merocercoids exposed. (D) Two opened cysts of M. grimaldi (white arrows) from the testis of $S$. coeruleoalba. (E) Exposed merocercoid of M. grimaldi (black arrow) and empty cyst (arrow head) in the broad ligament of the uterus of $S$. coeruleoalba; note a non related tumor (with arrow). (F) Brachycladium palliatum from hepatic ducts of S. coeruleoalba; insert shows a histological section of a trematode (black arrow) inside a bile duct initiating a slight nonsupurative inflammation (H\&E X4). (G) Nasitrema globicephalae in the air sinuses of S. coeruleoalba (black arrow) causing multiple erosions and mild sinusitis; magnification of a trematode in the paraotic sinuses is shown in the insert (white arrow). (H) Oschmarinella albamarina (white arrows) in the liver of Cuvier's beaked whale Ziphius cavirostris. (I) Anisakis spp. in the non glandular stomach of S. coeruleoalba. (J) Halocercus lagenorhynchi in the air passage of $S$. coeruleoalba; insert a granuloma (white arrow). (K) Kidney of $Z$. cavirostris showing atrophic ranulas (black arrows) caused by the presence of Crassicauda anthonyi. (L) C. anthonyi in the renal pelvis of $Z$. cavirostris opened kidney. 

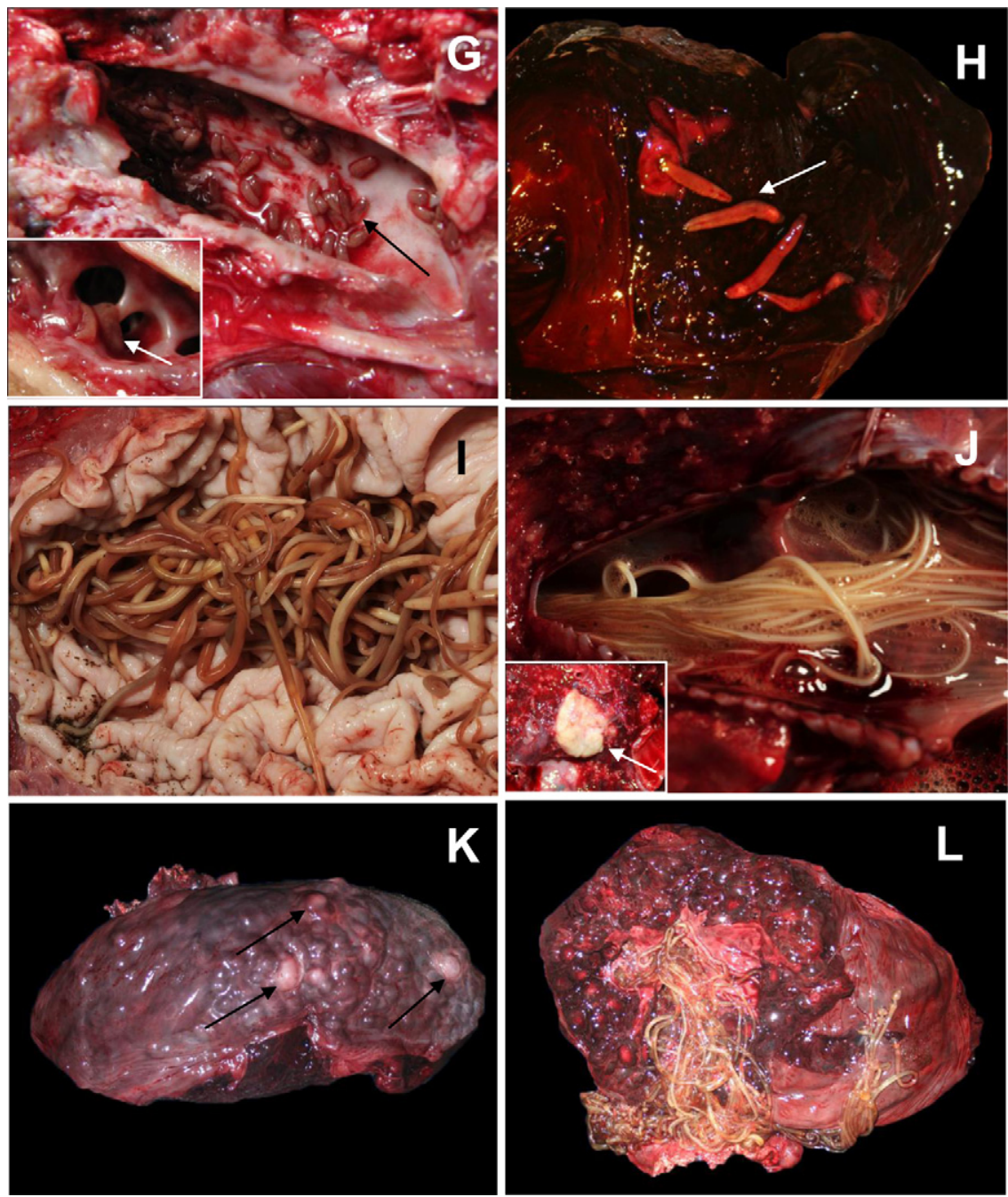

Fig. 1. (Continued).

Anisakis spp. was the most prevalent parasite (90.9\%). The following hosts were infected by this nematode: $S$. coeruleoalba, S. attenuata, S. longirostris and Z. cavirostris. Larvae and adults of Anisakis spp. were collected in different digestive organs as stomach (100\%), intestine (30\%) and esophagus (25\%) (Fig. 1). Four infected cetaceans presented a mild gastritis associated with a presence of parasites within the gastric mucosa.

H. lagenorhynchi (54.5\%) was collected in the lungs of striped dolphins S. coeruleoalba, whereas Halocercus sp. (9.1\%) was recovered from S. attenuata and S. longirostris. Adults of $H$. lagenorhynchi were collected in air passage of infected animals (Fig. 1), resulting in a moderate to severe granulomatous pneumonia associated with the presence of intralesional parasites.

The large nematode $C$. anthonyi was recovered from the kidneys of $Z$. cavirostris (4.5\%). Compressive necrosis and fibrosis were observed, due to the huge number of parasites (Figs. 1 and 2) at the urinary pelvis and in some areas of the renal parenchyma, resulting in partial destruction of the organ.

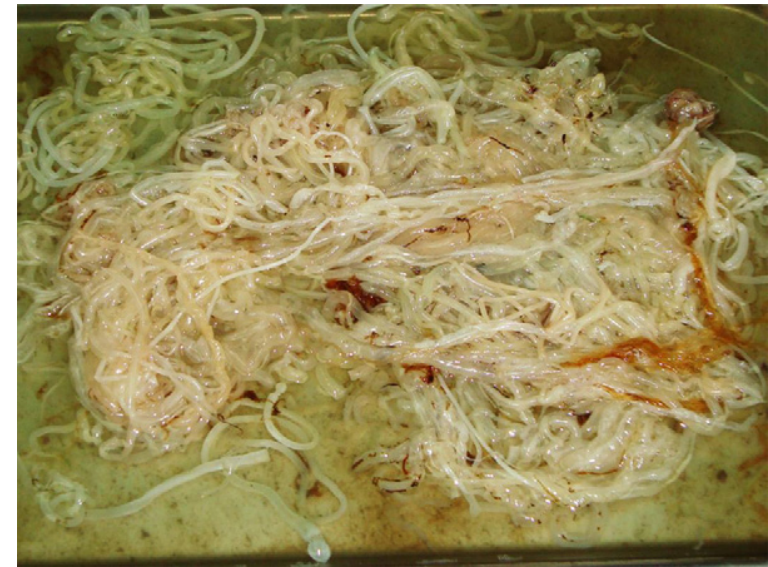

Fig. 2. Free nematodes C. anthonyi from the kidney of Ziphius cavirostris 


\subsection{Crustacea}

A pedunculate barnacle, identified as Xenobalanus globicipitis (Crustacea, Coronulidae), was found in the caudal fluke of S. coeruleoalba and S. attenuata.

\section{Discussion}

Parasites in marine mammals are relatively common and some of them have been implicated in disease processes and as one of the prominent causes of strandings of cetaceans (Gibson et al., 1998; Mignucci-Giannoni et al., 1998; Colón-Llavina et al., 2009). This is the first systematic survey regarding the parasitic fauna of cetaceans from Pacific coast of Costa Rica. All identified parasites and commensals representing new geographic records for the Pacific coast of Central America and increased the occurrence of some parasites to new hosts.

\subsection{Eucestoda}

Cestodes were one of the most representative group of parasites. Among several cestodes species that may be found in the intestine of cetaceans the easiest to identify (because of their enormous scolex) is $S$. triangularis, a parasite of dolphin's intestine particularly $S$. coeruleoalba (Hoberg, 1994; Dhermain et al., 2002). This tapeworm had been reported solely in $S$. coeruleoalba from the Pacific coast of the United States and Mediterranean Sea (Dailey and Stroud, 1978; Raga and Carbonell, 1985; Cerioni and Mariniello, 1996; Dhermain et al., 2002), and S. attenuata from Pacific coast of the United States (Dailey and Perrin, 1973). S. triangularis is considered as the most pathogenic cestode of dolphins because penetrates the colon wall initiating an inflammatory response (Dailey, 2001; Dhermain et al., 2002), which was not observed in this search probably because of the low intensity of parasitism. Massive infections with this species have been reported as probable cause of death in certain age categories of $S$. attenuata in United States (Dailey and Perrin, 1973).

Besides of $S$. triangularis, tetrabothriids were also represented by $T$. forsteri and Trigonocotyle sp. T. forsteri was the most prevalent, particularly in S. coeruleoalba and S. attenuata. This parasite has been also reported in S. coeruleoalba and $S$. attenuata from the United States, Spain and Italy (Dailey and Perrin, 1973; Dailey and Stroud, 1978; Raga and Carbonell, 1985; Cerioni and Mariniello, 1996). On the other hand, Trigonocotyle sp. was found only in S. longirostris, similar to reported by Aguilar et al. (2001) in Mexico. Neither T. forsteri as Trigonocotyle sp. appear to have not obvious pathogenic effect (Gibson et al., 1998; Aguilar et al., 2001).

Four types of tetraphyllidean metacestodes infect cetaceans worldwide: two plerocercoids differing in size, "small" (SP) and "large" (LP), and two merocercoids referred as P. delphini and M. grimaldii (Aznar et al., 2007). In this search, tetraphyllidean plerocercoids (SP and LP) were collected from the anal crypts, hepatic and pancreatic conducts of $S$. coeruleoalba and $S$. attenuata. There are records of plerocercoids recovered from $S$. coeruleoalba, Grampus griseus and $Z$. cavirostris stranded on the Mediterranean coast of Spain (Fernández et al., 2004; Agusti et al., 2005a) as well as from $S$. longirostris on the Pacific and Atlantic coasts of Mexico and Brazil respectively (Aguilar et al., 2001; Carvalho et al., 2010). For the first time S. attenuata is presented as new host of tetraphyllidean plerocercoids.

Tetraphyllidean plerocercoids, initially referred as Scolex pleuronectis (Skrjabin, 1972; Fernández et al., 2004; Agusti et al., 2005a), showed high prevalence and abundance as well as a high degree of site specificity, particularly in the anal crypts. Moreover, the two morphotypes of tetraphyllidean plerocercoids coexists in the same individual hosts have been reported in some cetacean species (Fernández et al., 2004; Agusti et al., 2005a; Aznar et al., 2007). Some authors have speculated that SP and LP morphotypes are thought to be earlier stages of $P$. delphini and $M$. grimaldi that presumed to infect large pelagic sharks that feed on cetaceans (Agusti et al., 2005a; Aznar et al., 2007). Nevertheless, molecular analysis showed that LP of $P$. delphini and $M$. grimaldi metacestodes may represent separate species, whereas SP may be conspecific with $M$. grimaldi (Aznar et al., 2007). In the present work, solely one specimen of S. coeruleoalba (ND2407) parasitized by SP and LP plerocercoids presented co-infection by $P$. delphini and $M$. grimaldi. It seems to be clear that cetaceans act as natural intermediate hosts for $P$. delphini and M. grimaldi, as within these hosts they undergo development from the plerocercoid stage to the merocercoid stage (Agusti et al., 2005a,b; Aznar et al., 2007).

Merocercoids of $P$. delphini and $M$. grimaldii are well known from most cetaceans worldwide and the typical sites of infection of these encysted metacestodes are the subcutaneous blubber and the abdominal cavity, respectively (Norman, 1997; Mignucci-Giannoni et al., 1998; Agusti et al., 2005a,b; Colón-Llavina et al., 2009). In the present study, specimens of the $P$. delphini occurred in the blubber solely from $S$. coeruleoalba, which was also reported in England, Wales, United States, Spain and Italy (Dailey and Stroud, 1978; Dailey and Walker, 1978; Baker, 1992; Cerioni and Mariniello, 1996; Gibson et al., 1998; Agusti et al., 2005a,b). On the other hand, specimens of $M$. grimaldi were found retroperitoneally encysted in different locations of the abdominal cavity including rectum, testis, at the broad ligament of the uterus and close to the kidneys of $S$. coeruleoalba, S. attenuata and T. truncatus. Previously, several authors reported them from $S$. coeruleoalba and S. attenuata in England, Wales, United States Spain and Italy (Dailey and Perrin, 1973; Dailey and Stroud, 1978; Dailey and Walker, 1978; Baker, 1992; Cerioni and Mariniello, 1996; Gibson et al., 1998; Agusti et al., 2005a,b). In Italy, merocercoids of $M$. grimaldi were found solely in the diaphragm of T. truncatus (Macchioni and Barducci, 1989).

\subsection{Digenea}

Several species of flukes have been documented in cetaceous worldwide (Dailey and Perrin, 1973; Raga, 1986; O'Shea et al., 1991; Gibson and Bray, 1997; Gibson et al., 1998; Degollada et al., 2002). N. globicephalae normally resides in the air sinuses of small cetaceans (O'Shea et al., 1991), which was found in S. coeruleoalba (a juvenile dol- 
phin) and S. attenuata (a senile dolphin) in this study. Degollada et al. (2002) observed a high prevalence of this parasite in the paraotic sinuses, ear complex, eighth cranial nerve and brain from $S$. coeruleoalba and T. truncatus stranded on the Canary Island. This is a new record of $N$. globicephalae in S. attenuata. Moderate ulcerative sinusitis and perineuritis of the eighth cranial nerve resulted of the presence of $N$. globicephalae in infected dolphins, but were not observed lesions in the brain. Differently of this investigation, brain lesions produced by Nasitrema have been implicated as a cause of death in single stranding of small cetaceans (Dailey and Walker, 1978; O'Shea et al., 1991; Degollada et al., 2002). However, it has not always been clear whether the trematode infection in the brain also debilitated the animal, leading to death from some secondary cause, or other events weakened the animals and allowed the parasites to invade the brain (O'Shea et al., 1991)

In a pantropical spotted dolphin (S. attenuata) infected by adults of $N$. globicephalae were also found trematode eggs in the lungs, which were morphologically indistinguishable those found in the air sinuses. O'Shea et al. (1991) noted a single Nasitrema sp. in the trachea of a striped dolphin stranded in the Gulf of Mexico; while Kumar et al. (1975) reported the potentialities of $N$. attenuata as an aetiological agent of pulmonary lesions in bottlenose dolphins (T. truncatus). According to Kumar et al. (1975), adults of $N$. attenuata occurring in the nasal sinuses and posterior nasal passage are considered as practically harmless for the host but their eggs, aspirated deep into the bronchial tree, may initiate a foreign-body of inflammatory reaction in the lungs and continuous aspiration of such eggs may provoke a chronic pneumonia condition. In the current survey, a slight granulomatous pneumonia was associated to the presence of trematode eggs. The eggs migration route of Nasitrema sp. is unclear.

Liver flukes $B$. palliatum (previously known as Campula palliata) and $B$. pacificum (previously known as Zalophotrema pacificum) were found in S. coeruleoalba and S. longirostris respectively, similar to reported in United States, Spain, Italy and Mexico (Dailey and Perrin, 1973; Lluch et al., 1987; Cerioni and Mariniello, 1996; Aguilar et al., 2001). Additionally, B. palliatum has been also reported in S. attenuata and T. truncatus from United States (Woodard et al., 1969; Dailey and Perrin, 1973). Parasitological information regarding to Cuvier's beaked whales $Z$. cavirostris is very limited (Demaree et al., 1997; Fernández et al., 2004; Berón-Vera et al., 2008) and the only record of digeneans in cetaceans of the family Ziphiidae was performed by Demaree et al. (1997), who identified a new species 0 . macrorchis from the liver sinuses of a Stejneger's beaked whale Mesoplodon stejnegeri. Thereby, Z. cavirostris is new host record for O. albamarina.

In this study, a slight nonsuppurative cholangitis was observed in all infected cetaceans. Likewise, there are numerous reports in the literature concerning the pathogenicity of liver flukes, which may produce severe damage to the bile ducts, eliciting focal suppurative cholangitis, severe necrotizing cholangitis or chronic granulomatous cholangitis (Gibson et al., 1998; Jaber et al., 2004, 2006). According to Woodard et al.(1969), pancreatic lesions occur with more regularity than the hepatic lesions in T. truncatus infected by B. palliatum.

\subsection{Nematoda}

Nematodes were one the most representative group of parasites.

Morphologically, all specimens recovered (adults and larvae) were identified as Anisakis genus. Nevertheless, species identification based on morphology is limited in this group of nematodes and the species identification is possible only through the use of genetic and molecular techniques (Mattiucci et al., 2002; Mattiucci and Nascetti, 2006). Anisakis genus include: A. simplex species complex (A. simplex s.s., A. simplex $\mathrm{C}$ and $A$. pegreffii), A. typica, $A$. ziphidarum, $A$. physeteris and $A$. brevispiculata (Mattiucci et al., 2002). All cetaceans studied in this survey are documented hosts for species of Anisakis and the major diversity (Anisakis sp., A. ziphidarum, A. typica and A. physeteris) have been reported from Cuvier's beaked whales in Puerto Rico, Virgin Islands and Spain (Mignucci-Giannoni et al., 1998; Fernández et al., 2004). Anisakis sp. and A. typica had been documented from S. longirostris in Puerto Rico, Virgin Islands and Mexico (Mignucci-Giannoni et al., 1998; Aguilar et al., 2001); while A. simplex is reported from $S$. coeruleoalba (Baker, 1992; Gibson et al., 1998) and S. attenuata (Dailey and Perrin, 1973). A molecular study should be performed for the identification of Anisakis species from Costa Rican cetaceans.

Larvae and adults of Anisakis spp. were found in stomach, intestine and esophagus. As observed in this work, the normal site for this worm is the stomach compartments; its occurrence outside this site is likely to be due to a post mortem migration (Gibson et al., 1998). Anisakis spp. is found within the lumen or attached to the mucosa of the stomach of marine mammals and can produce ulcers and cause hemorrhages (Abollo et al., 1998; Motta et al., 2008; Colón-Llavina et al., 2009). Four infected cetaceans presented a mild gastritis and no gastric ulcers were observed in any infected cetacean, similar to observed by Motta et al. (2008) in some cetaceans from Brazil. Anisakis spp. is medical and economic relevant because is a causative agent of human anisakiosis (Gibson et al., 1998).

In the current study $H$. lagenorhynchi was collected from the lungs of $S$. coeruleoalba, and Halocercus sp. from $S$. attenuata and S. longirostris. Previously, H. lagenorhynchi and Halocercus sp. has been recorded in S. coeruleoalba and S. longirostris from England, Wales and Brazil (Baker, 1992; Gibson et al., 1998; Carvalho et al., 2010); while $H$. lagenorhynchi and $H$. delphini are documented in $T$. truncatus and S. attenuata from Unites States and England (Dailey and Perrin, 1973; Dailey et al., 1991; Baker, 1992; Fauquier et al., 2009).

Parasitism of the respiratory system is a relatively common finding in stranded cetaceans, resulting in mild chronic lesions. Lungworms can be quite pathogenic, but the infections are not the primary cause of death (Gibson et al., 1998; Fauquier et al., 2009). The presence of parasites in the lungs of cetaceans stranded in Atlantic coast of Brazil was diagnosed as a highly debilitating condition, affecting respiratory capacity and diving (Carvalho et al., 2010). 
In the present study a moderate to severe granulomatous pneumonia was associated with the presence of intralesional Halocercus parasites. Signs of active and chronic multifocal granuloma and granulomatous bronchopneumonia (consistent with secondary involvement following a primary lungworm infection) were observed in cetaceans stranded in the British Virgin Islands (Mignucci-Giannoni et al., 1998). Additionally, verminous pneumonia limited to the area immediately surrounding the parasite-laden air passage was reported by Woodard et al. (1969) in captive and wild Atlantic bottlenose dolphin T. truncatus.

Previous records of Crassicauda in cetaceans include $C$. anthonyi, $C$. boopis and C. crassicauda (Mignucci-Giannoni et al., 1998; Colón-Llavina et al., 2009). According to Gibson et al. (1998), the female worms are enormous, reaching up to $7 \mathrm{~m}$ in length and $1 \mathrm{~cm}$ in diameter. This is probably the second largest known species of nematode (Gibson et al., 1998). In this survey, the spirurid C. anthonyi was found solely in the kidneys of $Z$. cavirostris, resulting in necrosis, fibrosis and partial destruction of the organ due to huge number of parasites, similar to reported in Australia and Puerto Rico (Robson, 1984; Mignucci-Giannoni et al., 1998). Because the tissue damages the crassicaudosis is a parasitic disease threatening the health and population recovery of cetaceans (Lambertsen, 1992).

\subsection{Crustacea}

$X$. globicipitis, a nonpathogenic crustacean, have been documented in S. coeruleoalba, S. attenuata and T. truncatus worldwide (Rajaguru and Shantha, 1992; Aznar et al., 1994; Carvalho et al., 2010). This barnacle is referred to as commensals because it only use their hosts for fixing (Aznar et al., 1994; Dhermain et al., 2002; Fertl, 2002; Carvalho et al., 2010). S. attenuata is presented as a new host of $X$. globicipitis.

\subsection{Final considerations}

The parasite fauna of marine mammals has not yet received all the necessary attention although they could be used as biological tags of marine mammal populations and as an aid assessing mortality. As observed by Gibson et al. (1998), in this work were identified parasites that occur in a wide range of hosts (e.g. Anisakis spp.), parasites which might be associated with stranding and/or mortality (e.g. N. globicephalae) or have definite pathogenic effects and debilitate their host (e.g. Anisakis spp., C. anthonyi, H. lagenorhynchi, Halocercus sp., B. palliatum, B. pacificum and $O$. albamarina). The parasitological information presented in the current study is valuable for conservation of cetaceans in Costa Rica.

\section{Acknowledgements}

We are very grateful to the participants and volunteers of the Fundación Keto. Cetaceans were collected thanks to agreement between the Ministerio de Medio Ambiente y Energía (MINAET), Fundación Keto and Escuela de Medicina Veterinaria de la Universidad Nacional. We thank Alexis
Berrocal and Leucio Câmara Alves for critical revision of this manuscript.

\section{References}

Abollo, E., Lopez, A., Gestal, C., Benavente, P., Pascual, S., 1998. Long-term recording of gastric ulcers in cetaceans stranded on the Galician (NW Spain) coast. Diseases of Aquatic Organisms 32, 71-73.

Aguilar, R., Moreno Navarrete, R.G., Salgado Maldonado, G., Villa Ramírez, B., 2001. Gastrointestinal helminths of spinner dolphins Stenella longirostris (Gray, 1828) (Cetacea: Delphinidae) stranded in La Paz Bay, Baja California Sur, Mexico. Comparative Parasitology 68, 272-274.

Agusti, C., Aznar, F.J., Raga, J.A., 2005a. Tetraphyllidean plerocercoids from western mediterranean cetaceans and other marine mammals around the word: a comprehensive morphological analysis. Journal of Parasitology 91, 83-92.

Agusti, C., Aznar, F.J., Olson, P.D., Littlewood, D.T., Kostadinova, A., Raga, J.A., 2005b. Morphological and molecular characterization of tetraphyllidean merocercoids (Platyhelminthes: Cestoda) of striped dolphins (Stenella coeruleoalba) from the Western Mediterranean. Parasitology 1304, 461-474.

Aznar, F.J., Raga, J.A., Balbuena, J.A., 1994. Are epizoites biological indicators of a western Mediterranean striped dolphin die-off? Diseases of Aquatic Organisms 18, 159-163.

Aznar, F.J., Agusti, C., Littlewood, D.T., Raga, J.A., Olson, P.D., 2007. Insight into the role of cetaceans in the life cycle of the tetraphyllideans (Platyhelminthes: Cestoda). International Journal of Parasitology 37, 243-255.

Baker, J.R., 1992. Cause of mortality and parasites and incidental lesions in dolphins and whales from British waters. Veterinary Record 130 , 569-572.

Berón-Vera, B., Crespo, E.A., Raga, J.A., 2008. Parasites in stranded cetaceans of Patagonia. Journal of Parasitology 94, 946-948.

Bush, A.O., Lafferty, K.D., Lotz, J.M., Shostak, A.W., 1997. Parasitology meets ecology in its own terms: Margolis et al revisited. Journal of Parasitology $83,575-583$.

Carvalho, V.L., Bevilaqua, C.M.L., Iñiguez, A.M., Mathews-Cascon, H., Ribeiro, F.B., Pessoa, L.M.B., Meirelles, A.C.O., Borges, J.C.G., Marigo, J., Soares, L., Silva, F.J.L., 2010. Metazoan parasites of cetaceans off the northeastern coast of Brazil. Veterinary Parasitology 173, 116-122.

Cerioni, S., Mariniello, L., 1996. Parasitic metazoans of Stenella coeruleoalba (Cetacea: Delphinidae) stranded along the coast of Latium, 1985-1991. Parassitologia 38, 505-510.

Colón-Llavina, M.M., Mignucci-Giannoni, A.A., Mattiucci, S., Paoletti, M., Nascetti, G., Williams Jr., E.H., 2009. Additional records of metazoan parasites from Caribbean marine mammals, including genetically identified anisakid nematodes. Parasitology Research 105 , 1239-1252.

Dailey, M.D., 2001. Parasites diseases. In: Dierauf, L.A., Gulland, F.M.D. (Eds.), CRC Handbook of Marine Mammal Medicine. CRC Press, Boca Raton, pp. 767-778.

Dailey, M.D., Perrin, W.F., 1973. Helminth parasites of porpoise of the genus Stenella in the Eastern Tropical Pacific, with descriptions of two new species: Mastigonema stenellae Gen. et sp. n. (Nematoda: Spiruroidea) and Zalophotrema pacificum sp. n. (Trematoda: Digenea). Fishery Bulletin 71, 455-471.

Dailey, M.D., Stroud, R., 1978. Parasites and associated pathology observed in cetaceans stranded along the Oregon coast. Journal of Wildlife Diseases $14,503-511$.

Dailey, M.D., Walker, W.A., 1978. Parasitism as a factor (?) in single strandings of southern California cetaceans. Journal of Parasitology 64, 593-596.

Dailey, M.D., Walsh, M., Odell, D., Campbell, T., 1991. Evidence of prenatal infection in the bottlenose dolphin (Tursiops truncatus) with the lungworm Halocercus lagenorhynchi (Nematoda: Pseudaliidae). Journal of Wildlife Diseases 27, 164-165.

Degollada, E., André, M., Arbelo, M., Fernández, A., 2002. Incidence, pathology and involvement of Nasitrema species in odontocete strandings in the Canary Islands. Veterinary Record 150, 81-82.

Demaree, R.S., Critchfield, R.L., Tinling, S.P., 1997. Oschmarinella macrorchis sp. n. (Digenea: Campulidae) from the liver sinuses of a beaked whale, Mesoplodon stejnegeri (Cetacea: Ziphiidae). Journal of the Helminthology Society of Washington 64, 183-187.

Dhermain, F., Soulier, L., Bompar, J.M., 2002. Natural mortality factors affecting cetaceans in the Mediterranean Sea. In: Di Sciara, N. (Ed.), Cetaceans of the Mediterranean and Black Seas: State of Knowledge and Conservation Strategies. A Report to the ACCOBAMS Secretariat, Monaco. (Section 15). 
Fauquier, D.A., Kinsel, M.J., Dailey, M.D., Sutton, G.E., Stolen, M.K., Wells, R.S., Gulland, F.M., 2009. Prevalence and pathology of lungworm infection in bottlenose dolphins Tursiops truncatus from southwest Florida. Diseases of Aquatic Organisms 88, 85-90.

Fernández, M., Aznar, F.J., Montero, F.E., Georgiev, B.B., Raga, J.A., 2004 Gastrointestinal helminthes of Cuvier's beaked whales, Ziphius cavirostris, from the western Mediterranean. Journal of Parasitology 90 , 418-420.

Fertl, D., 2002. Barnacles. In: Perrin, W.F., Würsig, B., Thewissen, H.G.M (Eds.), Encyclopedia of Marine Mammals. Academic Press, San Diego, pp. 75-78.

Gibson, D.I., 2005. Family Brachycladiidae Odhner, 1905. In: Jones, A., Bray, R.A., Gibson, D.I. (Eds.), Keys to the Trematoda, vol. 2. CAB International and the Natural History Museum, London, UK, pp. 641-652.

Gibson, D.I., Bray, R.A., 1997. Oschmarinella albamarina (Treshchev, 1968) n. comb., a liver fluke from the killer whale Orcinus orca (L.) of the British coast. Systematic Parasitology 36, 39-45.

Gibson, D.I., Harris, E.A., Bray, R.A., Jepson, P.D., Kuiken, T., Baker, J.R. Simpson, V.R., 1998. A survey of the helminth parasites of cetaceans stranded on the coast of England and Wales during the period 1990-1994. Journal of Zoology 244, 563-574.

Hoberg, E.P., 1994. Order Tetrabothriidea Baer, 1954. In: Khalil, L.F., Jones, A., Bray, R.A. (Eds.), Keys to the Cestode Parasites of Vertebrates. CAB International, Wallingford, pp. 295-304.

Jaber, J.R., Pérez, J., Arbelo, M., Andrada, M., Hidalgo, M., GómezVillamandos, J.C., Van den Ingh, T., Fernández, A., 2004. Hepatic lesions in cetaceans stranded in the Canary Islands. Veterinary Pathology 41, $147-153$.

Jaber, J.R., Pérez, J., Arbelo, M., Zafra, R., Fernández, A., 2006. Pathological and inmunohistochemical study of gastrointestinal lesions in dolphins stranded in the Canary Islands. Veterinary Record 159, 410-414.

Kumar, V., Vercruysse, J., Kageruka, P., Mortelmans, J., 1975. Nasitrema attenuata (Trematoda) infection of Tursiops truncatus and its potentialities as an aetiological agent of chronic pulmonary lesions. Journal of Helminthology 49, 289-292.

Lambertsen, R.H., 1992. La crassicaudose: une maladie parasitaire menacant la sante et la reconstitution des populations de gros mysticetes [gestion des systemes oceaniques: Crassicauda boopsis, grande baleine bleue (Balaenoptera musculus), rorqual (Balaenoptera physalus), jubarte (Megaptera novaeangliae)]. Revue Scientifique et Technique 11, 1131-1141.

Lluch, J., Roca, V., Navarro, P., 1987. Campula palliata (Looss, 1885) Looss, 1901 (Digenea: Campulidae) parásito del delfín listado (Stenella coeruleoalba Meyen, 1833) (Mammalia: Delphinidae). Boletín de la Real Sociedad Española de Historia Natural 83, 135-139.

Macchioni, G., Barducci, S., 1989. Reperti parassitologici nel delfino (Tursiops truncatus). Annali Della Facolta Di Medicina Veterinaria Di Pisa $42,137-143$.
Mattiucci, S., Nascetti, G., 2006. Molecular systematic, phylogeny and ecology of anisakid nematodes of the genus Anisakis Dujardin, 1845: an update. Parasite 13, 99-113.

Mattiucci, S., Paggi, L., Nascetti, G., Portes Santos, C., Costa, G., Di Beneditto, A.P., Ramos, R., Argyrou, M., Cianchi, R., Bullini, L., 2002. Genetic markers in the study of Anisakis typica (Diesing, 1860): larval identification and genetic relationships with other species of Anisakis Dujardin, 1845 (Nematoda: Anisakidae). Systematic Parasitology 51, 159-170.

Mignucci-Giannoni, A.A., Hoberg, E.P., Siegel-Causey, D., Williams Jr., E.H., 1998. Metazoan parasites and other symbionts of cetaceans in the Caribbean. Journal of Parasitology 84, 939-946.

Motta, M.R.A., Pinheiro, D.C.S.N., Carvalho, V.L., Viana, D.A., Vicente, A.C.P., Iñiguez, A.M., 2008. Gastric lesions associated with the presence of Anisakis spp. Dujardin, 1845 (Nematoda: Anisakidae) in Cetaceans stranded on the coast of Ceará, Brazil. Biota Neotropical 8, 91-95.

Norman, R.J.B., 1997. Tetraphyllidean cysticerci in the peritoneal cavity of the common dolphin. Journal of Wildlife Diseases 33, 891-895.

O'Shea, T.J., Homer, B.L., Greiner, E.C., Leyton, A.W., 1991. Nasitrema sp. - associated encephalitis in a striped dolphin (Stenella coeruleoalba) stranded in the Gulf of Mexico. Journal of Wildlife Diseases 27, 706-709.

Raga, J.A., 1986. Oschmarinella mascomai n. sp. (Trematoda: Campulidae) parasite des canaux biliaires de Stenella coeruleoalba (Meyen, 1833) (Cetacea: Delphinidae) en Méditerranée. Annales de Parasitologie Humaine et Comparée 61, 633-636.

Raga, J.A., Carbonell, E., 1985. New dates about parasites on Stenella coeruleoalba (Meyen, 1833) (Cetacea: Delphinidae) in the western Mediterranean Sea. Investigations on Cetacea 17, 207-213.

Raga, J.A., Balbuena, J.A., Aznar, J., Fernández, M., 1997. The impact of parasites on marine mammals: a review. Parasitologia 394, 293-296.

Raga, J.A., Fernández, M., Balbuena, J.A., Aznar, J., 2002. Parasites. In: Perrin, W.F., Würsig, B., Thewissen, H.G.M. (Eds.), Encyclopedia of Marine Mammals. Academic Press, San Diego, pp. 867-876.

Rajaguru, A., Shantha, G., 1992. Association between the sessile barnacle Xenobalanus globicipitis (Coronulidae) and the bottlenose dolphin Tursiops truncatus (Delphinidae) from the Bay of Bengal, India, with a summary of previous records from cetaceans. Fishery Bulletin 90, 197-202.

Robson, F.D., 1984. Strandings: ways to save whales. In: A Humane Conservation Guide. The Science Press, Johannesburg, South Africa, 124pp.

Skrjabin, A.S., 1972. Larvae of cestodes of the genus Phyllobothrium Beneden, 1850 (Tetraphyllidae), parasites of whales and other marine mammals. Parazitologiia 6, 426-434.

Stroud, R.K., Roffe, T.J., 1979. Cause of death in marine mammals stranded along the Oregon coast. Journal of Wildlife Diseases 15, 91-97.

Wehrtmann, I.S., Cortés, J., 2009. Marine Biodiversity of Costa Rica, Central America: Marine Mammals, vol. 42., 1st ed. Springer, pp. 479-495.

Woodard, J.C., Zam, S.G., Caldwell, D.K., Caldwell, M.C., 1969. Some parasitic diseases of dolphins. Veterinary Pathology 6, 257-272. 